Erik PAJTINKA*

\title{
THE PRACTICE OF APPOINTING EU AMBASSADORS: LA LANGUE EST-ELLE IMPORTANTE?
}

\begin{abstract}
The study tries to discover to what extent knowledge of the local language of a diplomat's host country, and language skills generally, are considered while selecting candidates for EU delegation heads in the European External Action Service. With this aim, the study examines possible correlations between languages spoken by the EU delegation heads and the official languages in their respective host countries. It is concluded that a correlation often exists between the language(s), and especially mother tongues, spoken by the EU delegation heads and the official language(s) in the countries to which they are posted and, thus, a candidate's knowledge of the host country's official language is usually taken into account in the selection of candidates for EU delegation heads, although this criterion seems to carry different weight for candidates from various EU member countries.
\end{abstract}

Keywords: EEAS, heads of EU delegations, EEAS staffing policy, EU diplomacy, languages in diplomacy

\section{Introduction}

Following the first common diplomatic service of the European Union, the European External Action Service (EEAS) was officially established by the Lisbon Treaty in December 2009. One of the most debated questions in the discussion on the EEAS' future organisation and functioning was the issue of recruitment rules and procedures, especially those relating to diplomatic staff and the EU delegation heads: de facto 'EU Ambassadors'. In the discussion, some EU member states, particularly those from Central and Eastern Europe, demanded the recruitment rules be based on national quotas, arguing that such quotas can best ensure a geographic balance among

* Erik Pajtinka, PhD, Assistant Professor, Faculty of Political Science and International Relations, Matej Bel University, Banská Bystrica, Slovak Republic

DOI: $10.51936 /$ tip.58.3.1117-1132

1 The study is published within the framework of the research project VEGA No. 1/0437/19 "The importance of the internationalization of higher education for the construction of the identity of the European Union and increasing competitiveness in the European area". 
the EEAS diplomatic staff. ${ }^{2}$ However, this opinion was not shared by the majority of EU member states and was eventually rejected. Instead, member states decided that professional qualification, and not nationality, should be the most important criterion while recruiting the EEAS' diplomatic staff. This principle was finally enshrined in a Council decision establishing the organisation and functioning of the EEAS, adopted in July 2010, which explicitly states "recruitment to the EEAS shall be based on merit" (Council Decision, 2010).

Interestingly, the early years of the EEAS' existence showed that some EU member states were relatively less successful than others in having their nationals appointed to the EEAS' diplomatic staff and they began to question why. Since recruitment of the EEAS' diplomatic staff was based on merit, less successful member states started to ask whether the professional qualification criteria, especially for the EU delegation heads, set out by the EEAS were in practice advantageous or disadvantageous for candidates from certain EU member states. In this study, we examine how language skills are considered in the selection of EU delegation heads.

In recent years, several academic publications have addressed questions pertaining to the EEAS' functioning. These publications mainly paid attention to general organisational and institutional aspects of the EEAS' operations (e.g. Austermann, 2014; Carta, 2014; Karalus, 2009), the legal context of its existence and operation (e.g. Petersen, 2011), selected issues of its internal organisation, like the gender balance and the national origins of its staff (e.g. Novotná, 2014) or interactions between the EEAS and the national diplomatic services of individual EU member states (e.g. Adebahr, 2013; Raik, 2013). Several works also examined the EEAS' staffing policy and the recruitment practices used while selecting diplomatic staff and the EU delegation heads. Formuszewicz and Liszczyk (2013) analysed the recruitment rules and procedures in the EEAS and their potential impact on the overall representation of EU member states, while Formuszewicz and Kumoch (2010) similarly examined various factors influencing the selection of candidates for the post of EU delegation head. In the latter, the question of language skills and their relevance in the process of selecting EU delegation heads was specifically mentioned. Still, this question is generally given little attention in academic literature. The aim of this article is to help fill this gap.

The objective of this study is to examine the relevance of language skills as a selection criterion for the EU delegation heads and, more concretely, to answer two questions: (a) whether knowledge of the host country's local

2 Geographic balance within the EEAS diplomatic staff should ensure that the EEAS would "draw from a wide variety of diplomatic cultures and experiences" (Rettman, 2010), that EU member states would "feel they have ownership of the service" and that their respective populations would believe "that the EU foreign policy institution works for their interests" (Eastern EU states, 2010). 
language is taken into account while selecting candidates for EU delegation heads; and (b) if the native-speaker level of knowledge of the host country's local language is particularly considered as an advantage in the selection of candidates for EU delegation heads. This will be done by evaluating a potential positive correlation between the number of speakers of a particular language among EU delegation heads and the number of those who serve in countries where the language concerned is an official one. Another aim of this article is to discern, by answering the mentioned questions, whether the language skill requirements set by the EEAS may explain the under- or overrepresentation of particular EU member states within the community of 'EU Ambassadors'.

It is important to note that this article does not intend to comprehensively analyse all of the factors that influence the selection procedures for EU delegation heads, but to highlight and analyse the relevance of the question of language skills during the process of selecting EU delegation heads because almost no attention has been paid to this issue by either academics or EU institutions.

The study is structured as follows. The first and second parts explain the specific position held by EU delegation heads in the EEAS' bureaucratic hierarchy and the relevance and importance of language skills as part of diplomat's professional qualifications. The third part of the study overviews the languages spoken by the EU delegation heads according to their countries of origin, while also comparing the official languages in countries with an EU Delegation with the languages spoken by the EU delegation heads accredited to those countries in order to demonstrate any correlation between the two. The final section of the study compares the official languages of the countries with EU Delegations and the nationalities of the EU delegation heads in those countries to show whether a correlation exists between the mother tongue and the nationality of the EU delegation head and the official language(s) in the host country.

This study relied primarily on interviews with EU delegation heads conducted by the author in July 2020 and, partly, on information published on the selected EU Delegations' official webpages.

\section{Data and methods}

The input data for our research, namely, data on nationality and languages spoken by the EU delegation heads were obtained from the EU delegation heads themselves by email, telephone surveys conducted by the author, and publicly accessible sources like the CVs of the EU delegation heads as published on EU institutions' official webpages. 
For practical reasons, the data on languages spoken by the EU delegation heads only include those languages in which the delegate is able to communicate in the most common situations encountered in their working life.

At the time of our survey, $133 \mathrm{EU}$ Delegations were accredited to third states. This number includes EU offices accredited to non-sovereign territories (such as Hong Kong) or third states only recognised by certain EU members (Kosovo), which officially are not EU Delegations but perform practically the same functions and are thus considered de facto EU Delegations. Conversely, the number does not include EU Delegations to international organisations, which were not the object of our research. Of the $133 \mathrm{EU}$ Delegations in third states, the post of the head was temporarily vacant in two delegations during the time of our survey. As a result, altogether 131 posts of the head of delegation were analysed. Complete data on nationality and languages spoken were available for 123 EU Delegations, while only data on nationality were available for 7 delegation heads. In the case of one delegation, in Nepal, neither data on the nationality nor the languages spoken by the head of the EU delegation were available.

\section{Heads of EU delegations and their position in the EEAS}

The post of EU delegation head is one of the most prominent and most prestigious positions in the EEAS institutional structure. To understand the importance of these posts, it is necessary to understand the roles and functions of individual categories of EEAS staff and their positions in the EEAS' bureaucratic hierarchy.

In accordance with EU regulations, the EEAS Staff falls into two basic groups: statutory staff and non-statutory staff. EEAS statutory staff are further divided into administrators (AD Staff), assistants (AST Staff), Contract Agents and Local Agents. The EEAS non-statutory staff comprise Stagiaires, Junior Professionals in Delegations, Seconded National Experts, who are employed by the national administrations of the EU member states, and external staff, contracted by private companies or job agencies to deliver specialised services or carry out short-term duties for the EEAS.

The AD Staff perform "managerial, conceptual and analytical duties" (Regulation No 31, 1962) which, in practice, include essentially the same tasks as carried out by diplomats in national diplomatic services. This also explains why this category of EEAS staff is often informally dubbed the EEAS' 'diplomatic staff'. Since the diplomatic activities are chiefly performed by the AD Staff, it is this category of EEAS staff that is most actively involved in implementing EU diplomacy itself. The significance of the tasks the AD Staff perform is reflected in the highest position this category of staff holds within the EEAS bureaucratic hierarchy. 
The other categories of EEAS staff are not usually directly involved in the performance of diplomatic activities, but instead perform various administrative and/or technical support tasks. Concretely, EEAS officials belonging to AST Staff or AST/SC Staff fulfil "executive and technical duties," or "clerical and secretarial duties" (Regulation No. 31, 1962) and typically assist the AD Staff in the performance of their tasks. In practice, the tasks carried out by the AST Staff are essentially very similar to those performed by administrative and technical personnel in the national diplomatic services.

The third category in the bureaucratic hierarchy of EEAS statutory staff contains Contract Agents. Officials falling into this staff category "carry out manual or administrative support service tasks" or perform duties in place of temporarily absent EEAS Staff members (European External Action Service, 2018). An important feature of this category of officials is that they work for the EEAS based on a fixed-term contract, and thus - unlike the officials in the AD Staff and AST Staff or AST/SC Staff categories - they do not work for the EEAS permanently.

The last category of EEAS statutory staff is Local Agents, who mostly fulfil "manual or service duties" (European External Action Service, 2018). This type of EEAS Staff - unlike all the preceding categories of EEAS Staff - does not work at the EEAS Headquarters in Brussels but is only found at external representations of the EU in third countries and at international organisations. Another specific feature of Local Agents is that positions in this category of EEAS Staff are not occupied by EU citizens but instead by the citizens of third countries - as a rule, the citizens of the country in which the particular EU representation operates.

The EU delegation heads are included in the AD staff, which - as mentioned - is the highest category of EEAS personnel in terms of their responsibilities and competences. Moreover, the EU delegation heads belong to management staff, ranking them among senior officials within this most important category of EEAS personnel. In addition, the EU delegation heads, unlike the vast majority of other officials occupying managerial posts in the EEAS, perform an important representational function relative to their host countries, where they are usually regarded as 'the voice and face' of the EU, thereby making these posts even more significant within the EEAS bureaucratic hierarchy.

\section{The relevance of language skills as part of a diplomat's professional qualifications}

Undoubtedly, language skills are an important part of a diplomat's professional qualifications. Knowing different languages enables a diplomat to communicate not only with other members of the diplomatic 
corps $^{3}$, but with the government authorities and the public in their host country. While for the purpose of communicating with other members of the diplomatic corps knowledge of the current lingua franca of diplomacy - English - is typically sufficient, to communicate with local government authorities, and especially the public of the host country, knowledge of the local official language is very useful, if not essential. In practice, in many countries, not all government officials speak English, and the same goes for business people, representatives of civil society and other groups with whom a diplomat usually needs to communicate in order to gather information, explain the policies of their own country or carry out other diplomatic duties. Further, the media usually use the local official language of the country and thus knowledge of this language allows a foreign diplomat to read the local newspapers and understand the news on local radio and television, namely, very important information sources about the development of the political and economic situation in the host country. This all illustrates how important knowledge of the local official language is for a diplomat. In this connection, it is not surprising that while selecting diplomats for posts in foreign countries the diplomatic services of many countries take account of the candidates' language skills, especially their knowledge of the host country's local official language. Accordingly, this question should also be relevant for the EEAS.

\section{The languages spoken by the heads of EU Delegations}

The languages spoken by the EU delegation heads and their mother tongues are shown in Table 1.

Table 1: LANGUAGES SPOKEN BY THE HEADS OF THE EU DELEGATIONS (HODS)

\begin{tabular}{|l|l|l|}
\hline Language & $\begin{array}{l}\text { No. of HoDs speaking this } \\
\text { language (among a total of } \\
\mathbf{1 2 3} \text { HoDs) }\end{array}$ & $\begin{array}{l}\text { No. of HoDs who are native } \\
\text { speakers of this language } \\
\text { (among a total of 123 HoDs) }\end{array}$ \\
\hline English & 123 & 4 \\
\hline French & 116 & 22 \\
\hline German & 59 & 20 \\
\hline Spanish & 56 & 12 \\
\hline Italian & 36 & 18 \\
\hline Russian & 27 & 0 \\
\hline Portuguese & 23 & 7 \\
\hline Dutch & 20 & 10 \\
\hline Arabic & 13 & 0 \\
\hline
\end{tabular}

3 The diplomatic corps is a community of all foreign diplomats who are accredited in one receiving country 


\begin{tabular}{|l|l|l|}
\hline Swedish & 10 & 3 \\
\hline Polish & 6 & 5 \\
\hline Greek & 6 & 5 \\
\hline Romanian & 4 & 2 \\
\hline Serbian & 4 & 0 \\
\hline Slovenian & 4 & 2 \\
\hline Croatian & 4 & 0 \\
\hline Finnish & 4 & 2 \\
\hline Czech & 4 & 2 \\
\hline Irish & 3 & 3 \\
\hline Chinese & 3 & 0 \\
\hline Danish & 3 & 3 \\
\hline Estonian & 3 & 3 \\
\hline Japanese & 2 & 0 \\
\hline Ukrainian & 2 & 0 \\
\hline Slovak & 2 & 2 \\
\hline Mongolian & 2 & 0 \\
\hline Latvian & 2 & 2 \\
\hline Bulgarian & 2 & 1 \\
\hline Swahili & 1 & 0 \\
\hline Bashkir & 1 & 0 \\
\hline Albanian & 1 & 0 \\
\hline Bosnian & 1 & 0 \\
\hline Lithuanian & 1 & 0 \\
\hline Maltese & 1 & 0 \\
\hline
\end{tabular}

Source: Email and telephone survey among the EU delegation heads conducted by the author in July 2020; EU Delegations' official websites, accessible at https://eeas.europa.eu/ headquarters/headquarters-homepage/area/geo_en, July 2020.

As Table 1 shows, the most widely spoken language among the EU delegation heads is English, where it is worth noting that English is the only language spoken by all (100\%) EU delegation heads. However, this is unsurprising since English is the present lingua franca of diplomacy and, at the same time, one of the three working languages of EU institutions. The second-most widely spoken language among the EU delegation heads is another working language of EU institutions, French. This language is spoken by about 94\% of EU delegation heads. Thus, English and French are by far the most widely spoken languages. All the other languages are spoken by considerably fewer delegation heads. German and Spanish, which are the third- and fourth-most widely spoken languages according to this study, are spoken by only about $48 \%$ and $46 \%$ of the EU delegation heads, respectively, while Italian is spoken by around 29\%. Interestingly, the sixthmost widely spoken language among the EU delegation heads is Russian. About 22\% of the EU delegation heads speak this language, making Russian the most widely spoken non-official EU language among the EU delegation heads. The seventh-most spoken language among the EU delegation 
heads is Portuguese. This language is spoken by about 19\% of EU delegation heads.

Looking specifically at the mother tongues of the EU delegation heads, the most common are French, German and Spanish, as shown in Table 1. These three languages have approximately the same share in mother tongues spoken by the EU delegation heads. French is the mother tongue of about $18 \%$ of all EU delegation heads, and German and Spanish at $16 \%$ and $15 \%$, respectively. The fourth-most common spoken mother tongue among the EU delegation heads is Italian. This language is spoken by about $10 \%$ of EU delegation heads. Interestingly, English, although the most widely spoken language among the EU delegation heads generally, is the mother tongue of only about $3 \%$ of them.

Table 2 provides an interesting perspective on the languages spoken by the EU delegation heads according to their country of origin.

Table 2: THE LANGUAGES SPOKEN BY THE EU DELEGATION HEADS ACCORDING TO THEIR COUNTRY OF ORIGIN

\begin{tabular}{|c|c|c|c|c|c|c|c|c|c|c|c|c|}
\hline \multirow[t]{2}{*}{$\begin{array}{l}\text { Language } \\
\text { English }\end{array}$} & \multicolumn{2}{|c|}{$\begin{array}{l}\text { HoDs from } \\
\text { France } \\
\text { speaking the } \\
\text { language } \\
\text { (among a } \\
\text { total of } 16 \text { ) }\end{array}$} & \multicolumn{2}{|c|}{$\begin{array}{l}\text { HoDs from } \\
\text { Germany } \\
\text { speaking the } \\
\text { language } \\
\text { (among a } \\
\text { total of 16) }\end{array}$} & \multicolumn{2}{|c|}{$\begin{array}{l}\text { HoDs } \\
\text { from Italy } \\
\text { speaking the } \\
\text { language } \\
\text { (among a } \\
\text { total of } 18 \text { ) }\end{array}$} & \multicolumn{2}{|c|}{$\begin{array}{l}\text { HoDs } \\
\text { from Spain } \\
\text { speaking the } \\
\text { language } \\
\text { (among a } \\
\text { total of 12) }\end{array}$} & \multicolumn{2}{|c|}{$\begin{array}{l}\text { HoDs from } \\
\text { CEE EU MS } \\
\text { speaking the } \\
\text { language } \\
\text { (among a } \\
\text { total of } 21 \text { ) }\end{array}$} & \multicolumn{2}{|c|}{$\begin{array}{l}\text { HoDs from } \\
\text { non-CEE EU } \\
\text { MS speaking } \\
\text { the language } \\
\text { (among a } \\
\text { total of } 102 \text { ) }\end{array}$} \\
\hline & 16 & $100 \%$ & 16 & $100 \%$ & 18 & $100 \%$ & 12 & $100 \%$ & 21 & $100 \%$ & 102 & $100 \%$ \\
\hline French & 16 & $100 \%$ & 16 & $100 \%$ & 17 & $94 \%$ & 12 & $100 \%$ & 16 & $76 \%$ & 100 & $98 \%$ \\
\hline Spanish & 7 & $44 \%$ & 5 & $31 \%$ & 11 & $61 \%$ & 12 & $100 \%$ & 2 & $10 \%$ & 54 & $53 \%$ \\
\hline Arabic & 1 & $6 \%$ & 2 & $13 \%$ & 2 & $11 \%$ & 1 & $8 \%$ & 4 & $19 \%$ & 9 & $9 \%$ \\
\hline Portuguese & 0 & $0 \%$ & 1 & $6 \%$ & 5 & $28 \%$ & 6 & $50 \%$ & 0 & $0 \%$ & 23 & $23 \%$ \\
\hline Russian & 2 & $13 \%$ & 4 & $25 \%$ & 1 & $6 \%$ & 1 & $8 \%$ & 15 & $71 \%$ & 12 & $12 \%$ \\
\hline Italian & 4 & $25 \%$ & 0 & $0 \%$ & 18 & $100 \%$ & 3 & $25 \%$ & 2 & $10 \%$ & 34 & $33 \%$ \\
\hline German & 8 & $50 \%$ & 16 & $100 \%$ & 3 & $17 \%$ & 1 & $8 \%$ & 10 & $48 \%$ & 49 & $48 \%$ \\
\hline
\end{tabular}

Source: Email and telephone survey among the EU delegation heads conducted by the author in July 2020; EU Delegations' official websites, accessible at https://eeas.europa.eu/ headquarters/headquarters-homepage/area/geo_en, July 2020.

As shown in Table 2, only English is widely spoken among the EU delegation heads from all the EU member states. French is also widely spoken by EU delegation heads from all EU member states, although it sees less use among those from Central and Eastern European (CEE) countries. Whilst about $98 \%$ of the EU delegation heads from non-CEE EU member states speak French, only about $76 \%$ of their colleagues from CEE countries speak this language. Still, it should be added that in the case of the EU delegation heads from non-CEE countries this percentage of French speakers includes a considerable number of delegates for whom French is their mother tongue. Without native speakers, the share of EU delegation heads from non-CEE 
countries speaking French would be about $76 \%$, that is the same percentage of French speakers who are from CEE EU member states.

Significantly less widely spoken by the EU delegation heads from CEE countries is Spanish. Only about 10\% of the EU delegation heads from CEE EU states speak this language, whilst about $53 \%$ of their colleagues from non-CEE countries are Spanish speakers. Portuguese is similarly much less widely spoken by the EU delegation heads from CEE EU member states, with none of these delegates speaking this language, whereas about 23\% of their colleagues from non-CEE EU member states do so. Yet, it should be noted that the shares of Portuguese-speaking EU delegation heads from different non-CEE countries vary considerably. This may be illustrated by the fact that Portuguese is spoken by about $50 \%$ of the EU delegation heads from Spain, but only $6 \%$ of German delegates can speak the language, and no French delegates can speak Portuguese. ${ }^{4}$ However, like with those who speak French, the share of EU delegation heads from non-CEE countries speaking Spanish, and Portuguese, also includes some native speakers. Without them, the share of Spanish- and Portuguese-speaking delegates from non-CEE countries would be about $41 \%$ and $16 \%$, respectively. These values, however, are still considerably higher than those of the EU delegation heads from CEE countries. In contrast, a language that is significantly more widely spoken by the EU delegation heads from the CEE EU member states is Russian. This language is spoken by about $71 \%$ of the EU delegation heads from CEE countries, but from non-CEE EU member states only about $12 \%$ speak Russian. Another language that is relatively more widely spoken by EU delegation heads from CEE EU member states is Arabic. About $19 \%$ of the EU delegation heads from CEE countries speak this language, whereas only about $9 \%$ of their colleagues from non-CEE EU member states are Arabic speakers.

\section{Official languages in countries with an EU delegation and the languages spoken by the EU delegation heads in these countries}

As illustrated in Table 3 below, English is the official language (or one of many official languages) in the highest number of countries with a resident EU delegation, although many countries with EU Delegations are also French-, Spanish- and Arabic-speaking. English, French, Spanish and Arabic are the official languages in 34,21, 18 and 17 countries, respectively, out of 130 countries with a resident EU delegation. Two languages - Russian and Chinese - are the official language in five and three countries with a resident

4 This is most likely due to the proximity of Portuguese and Spanish - the mother tongue of the EU delegation heads from Spain. 
EU delegation, respectively. In 96 out of 130 countries with an EU delegation, 1 or more of the 6 mentioned world languages are official languages and, in these countries, 85 out of 96 EU delegation heads (89\%) speak the official language(s) of the host country. Still, in 29 out of 130 countries with a resident EU delegation, no world or regional language is the official language. In these countries, only 3 out of 29 EU delegation heads, about 10\%, speak the local official language.

Examination of the official languages of countries with an EU delegation, and the languages spoken by the heads of the delegations in those countries, reveals the following. In all countries where the official language is English, Spanish and Russian, the head of the EU delegation speaks the local official language. In French-speaking countries, the situation is similar. About $95 \%$ of the EU delegation heads accredited to these countries speak French. ${ }^{5}$ In contrast, only about $41 \%$ of the EU delegation heads accredited to Arabic-speaking countries speak Arabic. Similarly, only 50\% of EU delegation heads in Portuguese-speaking countries are Portuguese speakers.

Looking specifically at the mother tongues of the EU delegation heads and their respective host countries, an interesting trend is observed. Concretely, a considerable number of EU delegation heads accredited mainly to Spanish-, French- and Portuguese-speaking countries are native speakers of their respective host countries' official languages. This is most notable in the case of Spanish-speaking countries where 8 out of $18 \mathrm{EU}$ delegation heads accredited to these countries, representing about $44 \%$, are native Spanish speakers. Similarly, in French-speaking countries, 7 out of 21 delegation heads (33\%) are native speakers of French. The same trend is seen in countries whose official language is Portuguese, with 2 out of $6 \mathrm{EU}$ delegation heads, again representing 33\%, being native Portuguese speakers. In addition, as shown by Table 3, the mother tongue of another 2 out of 6 delegates in Portuguese-speaking countries is Spanish, which is a language closely related to Portuguese. Thereby, together 4 out of 6 EU delegation heads in Portuguese-speaking countries, or about 66\%, are native speakers of Portuguese or of a language closely related to Portuguese. In contrast, neither of the two EU delegation heads in Italian-speaking countries is a native Italian speaker. Similarly, the mother tongue of the head of the only EU delegation in the German-speaking country is not German. It should be noted that this is not the outcome of a shortage of Italian or German native speakers among the EU delegation heads, because there are 18 native Italian speakers and 20 native speakers of German among the EU Ambassadors.

5 In absolute numbers, only 1 out of 21 EU delegation heads accredited to French-speaking countries does not speak French. 
Table 3: OFFICIAL LANGUAGES IN COUNTRIES WITH AN EU DELEGATION AND THE LANGUAGES SPOKEN BY THE HODS ACCREDITED IN THESE COUNTRIES

\begin{tabular}{|c|c|c|c|}
\hline Language & $\begin{array}{l}\text { No. of countries } \\
\text { with an EU } \\
\text { delegation where } \\
\text { the language is } \\
\text { an official one } \\
\text { (among a total of } \\
\text { 130) }\end{array}$ & $\begin{array}{l}\text { No. of countries with } \\
\text { an EU delegation where } \\
\text { the language (having } \\
\text { the status of an official } \\
\text { language) is spoken by } \\
\text { the HoD (among a total } \\
\text { of } 130 \text { ) }\end{array}$ & $\begin{array}{l}\text { No. of countries with } \\
\text { an EU delegation where } \\
\text { the language (having } \\
\text { the status of an official } \\
\text { language) is the mother } \\
\text { tongue of the HoD } \\
\text { (among a total of 130) }\end{array}$ \\
\hline English & 34 & 34 & 1 \\
\hline French & 21 & 20 & 7 \\
\hline \begin{tabular}{|l} 
Spanish \\
\end{tabular} & 18 & 18 & 8 \\
\hline Arabic & 17 & 7 & 0 \\
\hline Portuguese & 6 & 3 & 2 \\
\hline Russian & 5 & 5 & 0 \\
\hline Chinese & 3 & 2 & 0 \\
\hline Italian & 2 & 1 & 0 \\
\hline German & 1 & 1 & 0 \\
\hline All & 130 & 91 & 19 \\
\hline
\end{tabular}

Source: Email and telephone survey among the EU delegation heads conducted by the author in July 2020; EU Delegations' official websites, accessible at https://eeas.europa.eu/ headquarters/headquarters-homepage/area/geo_en, July 2020.

\section{Official languages in countries with an EU Delegation and nationalities of the EU delegation heads accredited in these countries}

By comparing official languages in countries with an EU Delegation and the nationalities of the heads of the EU Delegations accredited to those countries in Table 4, a certain correlation can be observed between the two. Specifically, the EU delegation heads from Spain, France and Portugal are posted relatively more often to countries whose official language is their own mother tongue. This can is shown by the fact that while the EU delegation heads from Spain represent only about $12 \%$ of all EU delegation heads in the world, their share in the total number of EU delegation heads in Spanish-speaking countries reaches nearly 44\%. In addition, in countries whose official language is Portuguese (which, again, is closely related to Spanish) the share of Spanish nationals in the total number of EU delegation heads is about 33\%. Similarly, whereas the share of the EU delegation heads from France in the total number of all EU delegation heads is only about $12 \%$, in French-speaking countries their share is more than double, at about 29\%. Likewise, in the case of the EU delegation heads from Portugal, their share in the total number of all EU delegation heads is only about 5\%, but in Portuguese-speaking countries they represent about 33\% of the EU delegation heads. In contrast, the EU delegation heads from Belgium, 
who are native French speakers, have almost the same share of the total number of all EU delegation heads and their number in French-speaking countries ( $5 \%$ in both cases). Thus, although the EU delegation heads from Belgium are native French speakers, just like their colleagues from France, unlike them, they are not more often posted to French-speaking countries. Similarly, the EU delegation heads from CEE EU member states are not relatively more often posted to Russian-speaking countries, even though Russian is much more widely spoken by them compared to their colleagues from non-CEE EU member states. This is illustrated by the fact that, although delegation heads from CEE EU member states constitute $16 \%$ of the total number of all EU delegation heads, this figure in Russian-speaking countries is only slightly higher, about $20 \%$.

Table 4: OFFICIAL LANGUAGES IN COUNTRIES WITH AN EU DELEGATION, AND NATIONALITIES AND MOTHER TONGUES OF THE EU DELEGATION HEADS ACCREDITED IN THESE COUNTRIES

\begin{tabular}{|c|c|c|c|c|c|c|c|}
\hline \multirow[t]{2}{*}{ Language } & \multirow{2}{*}{$\begin{array}{l}\text { No. of countries } \\
\text { with an EU } \\
\text { delegation where } \\
\text { the language is an } \\
\text { official one (among } \\
\text { a total of 130) }\end{array}$} & \multicolumn{6}{|c|}{$\begin{array}{l}\text { Nationality and mother tongue of the HoDs } \\
\text { accredited in these countries }\end{array}$} \\
\hline & & $\begin{array}{l}7 \\
\stackrel{7}{0} \\
\overparen{O}\end{array}$ & $\begin{array}{l}\stackrel{Q}{0} \\
\stackrel{\Xi}{\Xi} \\
\stackrel{0}{0}\end{array}$ & 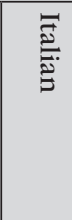 & 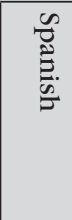 & 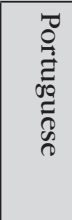 & 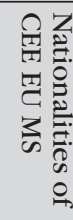 \\
\hline English & 34 & 3 & 5 & 5 & 4 & 1 & 7 \\
\hline French & 21 & 6 & 3 & 4 & 1 & 3 & 1 \\
\hline Spanish & 18 & 2 & 1 & 4 & 8 & 1 & 0 \\
\hline Arabic & 17 & 3 & 4 & 5 & 1 & 0 & 2 \\
\hline Portuguese & 6 & 1 & 0 & 0 & 2 & 2 & 1 \\
\hline Russian & 5 & 0 & 2 & 0 & 1 & 0 & 1 \\
\hline Chinese & 3 & 1 & 0 & 0 & 1 & 0 & 1 \\
\hline Italian & 2 & 0 & 0 & 0 & 0 & 0 & 1 \\
\hline German & 1 & 0 & 0 & 0 & 0 & 0 & 0 \\
\hline
\end{tabular}

Source: Email and telephone survey among the EU delegation heads conducted by the author in July 2020; EU Delegations' official websites, accessible at https://eeas.europa.eu/ headquarters/headquarters-homepage/area/geo_en, July 2020.

When looking at the number of EU delegation heads by nationality and languages spoken in their respective host countries, it can be seen that 19 out of 130 EU delegation heads, or about 15\%, are accredited to a foreign country whose official language is their own mother tongue. The highest number of these EU delegation heads, 8 and 7, are of Spanish and French nationality, respectively. The remaining 4 out of $19 \mathrm{EU}$ delegation heads who serve in a foreign country, whose official language is their own mother tongue, are Belgian, Irish and Portuguese nationals. Curiously, none of the EU delegation heads of Austrian, Croatian, German, Italian or Romanian 
nationality are accredited to a foreign country whose official language is their mother tongue, even though EU Delegations do exist in such countries and thus one would expect to find such a posting.

It should also be mentioned that of the total number of EU delegation heads of Spanish and French nationality, 50\% and about 44\% are accredited to Spanish- and French-speaking countries, respectively. On the other hand, only about 33\%, 29\% and 17\% of Irish, Portuguese and Belgian nationals serving as EU delegation heads, respectively, are accredited to countries whose official language is their own mother tongue, as shown in Table 5.

Table 5: EU DELEGATION HEADS AND THEIR KNOWLEDGE OF THE OFFICIAL LANGUAGES OF THEIR RESPECTIVE HOST COUNTRIES BY NATIONALITY

\begin{tabular}{|l|l|l|l|}
\hline Nationality & $\begin{array}{l}\text { No. of } \\
\text { HoDs }\end{array}$ & $\begin{array}{l}\text { No. of HoDs who are } \\
\text { native speakers of the } \\
\text { official language of } \\
\text { their host country }\end{array}$ & $\begin{array}{l}\text { No. of HoDs who are speakers } \\
\text { of the official language of } \\
\text { their host country (including } \\
\text { native speakers) }\end{array}$ \\
\hline Austrian & 4 & - & 2 \\
\hline Belgian & 6 & 1 & 4 \\
\hline British & 1 & - & - \\
\hline Bulgarian & 1 & - & - \\
\hline Cypriot & 2 & - & 1 \\
\hline Czech & 2 & - & 1 \\
\hline Danish & 3 & - & 2 \\
\hline Dutch & 5 & - & 2 \\
\hline Estonian & 3 & - & 1 \\
\hline Finnish & 2 & - & 1 \\
\hline French & 16 & 7 & 12 \\
\hline German & 16 & - & 11 \\
\hline Greek & 3 & - & 2 \\
\hline Hungarian & 1 & - & 1 \\
\hline Irish & 3 & 1 & 3 \\
\hline Italian & 19 & - & 14 \\
\hline Latvian & 2 & - & 1 \\
\hline Lithuanian & 1 & - & - \\
\hline Maltese & 1 & - & 1 \\
\hline Polish & 5 & - & 4 \\
\hline Portuguese & 7 & 2 & 7 \\
\hline Romanian & 2 & - & 2 \\
\hline Slovak & 2 & - & 2 \\
\hline Slovenian & 2 & - & 1 \\
\hline Spanish & 16 & 8 & $14^{*}$ \\
\hline Swedish & 5 & - & $2^{*}$ \\
\hline Total & 130 & 19 & 91 \\
\hline Source & & - & \\
\hline
\end{tabular}

Source: Email and telephone survey among the EU delegation heads conducted by the author in July 2020; EU Delegations' official websites, accessible at https://eeas.europa.eu/ headquarters/headquarters-homepage/area/geo_en, July 2020. 
Table 5 shows that 91 out of 130 EU delegation heads, about $70 \%$, speak the official language (or at least one of the official languages) of their respective host countries. This number includes native speakers of the host country's official language, who themselves represent about $15 \%$ of all EU delegation heads, as mentioned.

\section{Conclusion}

The data presented make it obvious that there is often a certain correlation between the language(s) spoken by the EU delegation heads and the official language(s) in the countries where they are posted. A good example of this is that Spanish is spoken by about $46 \%$ of the EU delegation heads, but by $100 \%$ of those accredited to countries in which Spanish is an official language. Other notable examples are Portuguese and Russian, spoken by only about $19 \%$ and $22 \%$ of all EU delegation heads, respectively, but by about $50 \%$ and $100 \%$ of those who are posted in Portuguese- and Russianspeaking countries. These findings allow the conclusion that in the process of selecting candidates for positions of EU delegation heads a candidate's knowledge of the official language of the host country is certainly taken into account.

At the same time, the data presented in this article show there is often a significant correlation between the mother tongues of the EU delegation heads and the official language(s) of their respective host countries. This is demonstrated by the data for Spanish, which is the mother tongue of about $15 \%$ of all EU delegation heads, but of about $44 \%$ of those posted to Spanish-speaking countries. Similarly, French and Portuguese are the mother tongues of only about $18 \%$ and $6 \%$, respectively, of all EU delegation heads, yet are the mother tongues of about $33 \%$ of those accredited in countries where the official language is French or Portuguese.

Interestingly, a correlation between the mother tongues of the EU delegation heads and official languages of their respective host countries can only be observed in the case of the EU delegation heads from France, but not in the case of their colleagues from Belgium, who are also French native speakers. This may indicate that it is not the mother tongue but the nationality that is considered while selecting candidates for EU delegation heads. Of course, this is difficult to assess in the cases of the EU delegation heads from Spain and Portugal since the sets of Spanish and Portuguese nationals and Spanish and Portuguese native speakers, respectively, overlap completely.

Overall, it may be concluded based on the above observations that knowledge of the host country's official language is certainly a factor while selecting candidates for posts of EU delegation heads, althogh this criterion seems to have a varying weight in the evaluation of candidates from 
different EU member states. Further research should determine whether this is a consequence of the political lobbying of individual EU member states for 'their' candidates, taking account of other professional qualities (e. g. specific expertise) or both.

\section{BIBLIOGRAPHY}

Adebahr, Cornelius (2013): The Good Europeans: Germany and the European External Action Service. In Rosa Balfour and Kristi Raik (eds.), The European External Action Service and National Diplomacies, 13-22. Brussels: European Policy Centre.

Austermann, Frauke (2014): European Union Delegations in EU Foreign Policy. A Diplomatic Service of Different Speeds. Houndmills and New York: Palgrave Macmillan.

Carta, Caterina (2014): The Diplomatic System of a Non-State Actor. In Doris Dialer and Heinrich Neisser, Anja Opitz (eds.), The EU's External Action Service: Potentials for a One Voice Foreign Policy, 33-44. Innsbruck: Innsbruck University Press.

N.A. (2010) Eastern EU states battle for posts in new foreign service. In Times of Malta, 12 September 2010 [online]. Accessible at https://www.timesofmalta. com/articles/view/20100912/world/eastern-eu-states-battle-for-posts-in-newforeign-service.326615, 10.1.2021.

Formuszewicz, Ryszarda and Dorota Lyszczyk (2013): The Staffing Policy of the European External Action Service - Stocktaking Ahead of the 2013 Review. In The Polish Quarterly of International Affairs 9 (1): 139-160.

Formuszewicz, Ryszarda and Jakub Kumoch (2010): The Practice of Appointing the Heads of EU Delegations in the Wake of Council Decision on the European External Action Service. Warsaw: The Polish Institute of International Affairs.

Karalus, Kristin (2009): Die diplomatische Vertretung der Europäischen Union. Tübingen: Mohr Siebeck.

Novotná, Tereza (2014): Who's in Charge? Member States, EU Institutions and European External Action Service. ISPI Policy Brief 228: 1-13.

Petersen, Lars Ole (2011): Europäisierung der Diplomatie. Völker- und europarechtliche Rahmenbedingungen. Berlin: Duncker \& Humblot.

Raik, Kristi (2013): Finland and the European External Action Service. In Rosa Balfour and Kristi Raik (eds.), The European External Action Service and National Diplomacies, 75-84. Brussels: European Policy Centre.

Rettman, Andrew (2010): New EU states make bid for more diplomatic clout. In EU Observer, 10 March 2010 [online]. Accessible at https://euobserver.com/ institutional/39651, 15. 1. 2021.

SOURCES

Council Decision of 26 July 2010 establishing the organisation and functioning of the European External Action Service (2010/427/EU) (2010): Published in Official Journal of the European Union, L201. 
European External Action Service. EEAS Human Resources Annual Report 2017 (2018): Brussels, European External Action Service.

EU Delegations' official websites, accessible at https://eeas.europa.eu/headquarters/headquarters-homepage/area/geo_en, July 2020.

Regulation No 31 (EEC), 11 (EAEC), laying down the Staff Regulations of Officials and the Conditions of Employment of Other Servants of the European Economic Community and the European Atomic Energy Community (1962): The Official Journal of the European Communities, P045, 14. 6. 1962: 1385. 